\title{
Long-term Effects of Chemical Control \\ of Big Sagebrush
}

JOHN F. THILENIUS AND GARY R. BROWN

Highlight: In 1960 and 1961, big sagebrush (Artemisia tridentata) on four cattle ranges in the Bighorn Mountains was sprayed with 2,4-D. By 1971, the canopy cover of big sagebrush was $8.42 \%$ of the pretreatment levels, seedling density ranged from 5.7-11.3 plants $/ 120 \mathrm{ft}^{2}$, herbage production was below the pretreatment levels with the proportion of graminoids about equal to that prior to spraying. Effects of grazing deferment for as long as 3 years after spraying could not be detected.

Deferment of cattle grazing for as long as 3 years after herbicidal control (2,4-D) of big sagebrush (Artemisia tridentata) had no effect on subsequent herbage production or subsequent big sagebrush reinvasion in the Bighorn Mountains of Wyoming (Smith, 1969). Smith's study was conducted between 1959 and 1966. We resampled the same ranges in 1971 to assess the long-term effects of sagebrush control.

Smith used four sites in his study. Two of them (Antelope Butte and Soldier Creek) were sprayed in 1960; the other two (Buck Creek and Grouse Creek) in 1961. We were able to adequately resample the Antelope Butte, Soldier Creek, and Buck Creek sites. A division fence and water development had been constructed on the Grouse Creek site; becausc of heavy forage utilization and trampling, we could measure only coverage of big sagebrush at this location.

\footnotetext{
The authors are, respectively, range scientist and range research technician, Rocky Mountain Forest and Range Experiment Station, Forest Service, U.S. Department of Agriculture. Research reported here was conducted at the Station's Research Work Unit at Laramie, in cooperation with the University of Wyoming. Station's central headquarters is maintained at Fort Collins, in cooperation with Colorado State University.

Manuscript received September 12, 1973.
}

There are no quantitative data available on the grazing management on any of the sites between 1966 and 1971 . During this period, new management systems were initiated on the cattle allotments where the study sites are located. The Soldier Creek and Antelope Butte sites are both near water and are grazed rather heavily throughout the growing season, while the Buck Creek site is grazed more lightly and later in the season.

Data were obtained from the original sample locations by the same techniques. Canopy coverage of big sagebrush was sampled by the line-intercept method (Canfield, 1942); vegetation production by the weight estimate method (Pechanec and Pickford, 1937) adjusted by double sampling (Wilm et al., 1944). The density of big sagebrush seedlings was determined on the same sample plots used to estimate herbage production.

Table 1. Canopy cover (\%) of big sagebrush prior (1959-1960) to spraying with 2,4-D and at 3 dates of measurement after spraying.

\begin{tabular}{lcccc}
\hline \multicolumn{1}{c}{ Site } & $1959-$ & $1960-$ & $1965-$ & \\
\hline Antelope Butte & 1960 & 1961 & 1966 & 1971 \\
Soldier Creek & 24.4 & 0.1 & 0.0 & 2.4 \\
Buck Creek & 14.6 & 0.0 & 0.0 & 1.9 \\
Grouse Creek & 15.5 & 0.1 & 1.2 & 6.6 \\
\hline
\end{tabular}

\section{Results and Discussion}

\section{Canopy Cover and Density of Big} Sagebrush

The data on canopy cover in 1971 cannot be related to length of deferment because the line-intercept transects were not located within the deferred areas. Therefore, they refer only to the general increase of big sagebrush cover. Big sagebrush was absent, or nearly so, at all four sites the year after spraying (Table 1). Five years later, big sagebrush reinvasion could be detected only at the Grouse Creek site, where it had increased to about $8 \%$ of the pretreatment level.

By 1971, some reinvasion was apparent at all sites. Only at Grouse Creek, however, was canopy cover of big sagebrush relatively high-about $42 \%$ of what it was prior to spraying in 1959. The reason for the greater increase at Grousc Creek is not known. There is no evident relationship between pretreatment sagebrush cover or the degree of control (which was high at all sites) and the cover in 1971.

We were able to remeasure the density of big sagebrush seedlings only at the

Table 2. Density (plants/120 $\mathrm{ft}^{2}$ ) in 1971 of big sagebrush seedlings as affected by length of deferment af ter sagebrush control.

\begin{tabular}{lrrrrr}
\hline \hline & \multicolumn{5}{c}{ Years deferred } \\
\cline { 2 - 6 } \multicolumn{1}{c}{ Site } & 0 & 1 & 2 & 3 & Avg \\
\hline Antelope Butte & 17 & 6 & 3 & 8 & 11.3 \\
Soldier Creek & 8 & 13 & 19 & 15 & 18.3 \\
Buck Creek & 5 & 3 & 2 & 7 & 5.7 \\
$\quad$ Average & 10.0 & 7.3 & 8.0 & 10.0 \\
\hline
\end{tabular}


Antelope Butte, Soldier Creek, and Buck Creek sites (Table 2). There were no statistically significant differences $(\propto=$ 0.05 ) either between treatments or between sites in 1971. We also compared the density of big sagebrush seedlings in 1971 with the density for the years 1960-1965. Smith reported significant differences at Antelope Butte for 2 and 3 years of deferment. Our analysis showed no signficant differences either between years or between length of deferment period at any of the sites.

The yearly variation in seedling density was highly variable within a given site, even though density was recorded on the same plots each year. Apparently, as Smith also found during the 1960-1966 period, seedling mortality is high and there is no uniform annual increase in density. This is somewhat contradictory to the results reported by Johnson (1969) who found sagebrush density on grazed ranges had returned to the prespraying level 14 years after treatment. However, the areas studied by Johnson were located in the sagebrush steppe zone, while our areas are in the montane sagebrush zone. The former environment might be more favorable to the survival and growth of big sagebrush.

\section{Herbage Production}

Total production of herbage in 1971

Table 3. Herbage production (lb/acre, air-dry) in 1971 , as affected by length of deferment after sagebrush control.

\begin{tabular}{lllr}
\hline $\begin{array}{l}\text { Site and length } \\
\text { of deferment }\end{array}$ & Graminoids & Forbs & Total \\
\hline $\begin{array}{lllr}\text { Antelope Butte } \\
\text { 0 years }\end{array}$ & 225 & 663 & 888 \\
1 year & 262 & 758 & 1020 \\
2 years & 274 & 737 & 1011 \\
3 years & 248 & 751 & 999 \\
Average & 253 & 727 & 980 \\
Soldier Creek & & & \\
0 years & 359 & 672 & 1031 \\
1 year & 317 & 685 & 1002 \\
2 years & 312 & 807 & 1119 \\
3 years & 291 & 467 & 758 \\
Average & 319 & 658 & 977 \\
Buck Creek & & & \\
0 years & 260 & 711 & 971 \\
1 year & 174 & 968 & 1142 \\
2 years & 226 & 942 & 1168 \\
3 years & 249 & 700 & 949 \\
Average & 228 & 830 & 1058 \\
Average: all sites & & & \\
0 years & 281 & 682 & 962 \\
1 year & 251 & 804 & 1054 \\
2 years & 270 & 829 & 1099 \\
3 years & 263 & 639 & 902 \\
Average & 267 & 738 & 1005 \\
\hline
\end{tabular}

Table 4. Average herbage production (lb/acre, air-dry) for all deferment treatments, and contribution of graminoids $(\%)$ to herbage.

\begin{tabular}{|c|c|c|c|c|c|c|}
\hline \multirow[b]{2}{*}{ Year } & \multicolumn{2}{|c|}{ Antelope Butte } & \multicolumn{2}{|c|}{ Soldier Creek } & \multicolumn{2}{|c|}{ Buck Creek } \\
\hline & Herbage & Graminoids & Herbage & Graminoids & Herbage & Graminoids \\
\hline 1959 & 1510 & 21 & 2259 & 35 & $\left({ }^{1}\right)$ & $\left({ }^{1}\right)$ \\
\hline 1960 & $687^{2}$ & 61 & $603^{2}$ & 69 & 1060 & 25 \\
\hline 1961 & 627 & 57 & 821 & 95 & $466^{2}$ & 77 \\
\hline 1962 & 1513 & 63 & 1732 & 88 & 805 & 76 \\
\hline 1963 & 1220 & 65 & 1061 & 70 & 1750 & 75 \\
\hline 1964 & 428 & 47 & 410 & 57 & 442 & 55 \\
\hline 1965 & 639 & 36 & 1368 & 36 & 1131 & 51 \\
\hline 1966 & $\left({ }^{1}\right)$ & $\left({ }^{1}\right)$ & $\left({ }^{1}\right)$ & $\left({ }^{1}\right)$ & 916 & 51 \\
\hline 1971 & 980 & 26 & 977 & 32 & 1058 & 21 \\
\hline Average & 951 & 47 & 1153 & 60 & 953 & 54 \\
\hline
\end{tabular}

Not sampled.

${ }^{2}$ Year of spraying.

(Table 3) ranged from 758 to $1168 \mathrm{lh} /$ acre (air-dry). The length of the deferment period had no statistically significant effect on production of graminoids, forbs, or total herbage. Production differences between the three sites in 1971 were also nonsignificant.

Statistical comparisons between production data for 1971 and previous years (Table 4) are difficult to interpret because of unknown variations in environment and grazing management. However, total herbage production was significantly less in 1971 than it was prior to treatment (1959) on the Antelope Butte and Soldier Creek sites and almost exactly equal on the Buck Creek site.

Total herbage production after sagebrush control on the Antelope Butte site exceeded the 1971 values only in 1962 and 1963, and was significantly higher only in 1962. On the Soldier Creek site, total production exceeded that of 1971 in 3 years, but never significantly. At Buck Creek, total herbage production was greater than that of 1971 only in 1963 and 1965, and the difference was significant only in 1963. At all sites, postspraying production was greatest 2 years (three growing seasons) after herbicidal treatment, regardless of the year of control. Production after the year of peak growth was variable. It was particularly low on all sites in 1964, apparently a year of very poor growing conditions.

The trend in the proportion of graminoids in the forage varied slightly between sites. At Antelope Butte, graminoids were most abundant in 1963 , four growing seasons after control. At Soldier Creek graminoid production was maximum the second growing season after spraying, when $95 \%$ of the herbage was either grasses or sedges. At Buck Creek, graminoids contributed from 75 to $77 \%$ of the herbage for 3 years after the herbicide was applied. Depending on the site, the proportion of graminoids in the herbage declined 13 to 20\% from 1964 onward. In 1971, the graminoid contribution on all sites was close to what it was the year before the sagebrush was controlled, even though total herbage production was either less or equal to that prior to treatment.

\section{Summary}

On three summer cattle ranges in the Bighorn increased herbage production after sagebrush control with 2,4-D was a relatively short-lived phenomenon. Declines in production and in the proportion of graminoids in the herbage did not appear to be related to reinvasion of sagebrush as this was minimal on all three sites even after 10 to 11 years. The proportion of graminoids in the herbage was very close to that prior to the herbicide treatment and total herbage production was below pretreatment levels on all three sites. Deferment from cattle grazing for as long as 3 years after sagebrush control had no effect on herbage production as measured in 1971 .

\section{Literature Cited}

Canfield, R. H. 1942. Sampling ranges by the line interception method. U. S. Dep. Agr., Forest Serv., Southwest. Forest and Range Exp. Sta., Sta. Rep. 4. 27 p.

Johnson, W. M. 1969. Life expectancy of a sagebrush control in central Wyoming. J. Range Manage. 22:177-182.

Pechanec, J. F., and G. D. Pickford. 1937. A weight estimate method for determination of range or pasture production. J. Amer. Soc. Agron. 29:894-904.

Smith, D. R. 1969. Is deferment always needed after chemical control of sagebrush? J. Range Manage. 22:261-263.

Wilm, H. G., David F. Costello, and G. E. Klipple. 1944. Estimating forage yield by the double-sampling method. J. Amer. Soc. Agron. 36:194-203. 